\title{
Mortadella formulations using poultry breasts with White Striping and Wooden Breast
}

Formulações de mortadela usando peitos de frango com listra branca e peito de madeira

\section{Jair Rodrigues de Oliveira ${ }^{1}$, Sabrina Tolotti Fraga Teixeira ${ }^{1}$, Rafael Levandowski ${ }^{2}$, Luciana} Ruschel dos Santos ${ }^{3 *}$, Elci Lotar Dickel ${ }^{3}$

\begin{abstract}
Were prepared mortadella formulations using poultry breasts with White Stripping and Wooden Breast in order to use this raw material. The mortadellas were formulated with $25 \%, 50 \%, 75 \%$ and $100 \%$ of breasts with WS or WB and without alterations (WA). Were performed a microbiological evaluation, centesimal composition (protein, moisture, lipids and ashes), $\mathrm{pH}$ and Eber reaction of mortadella formulated at 30 and 60 days post processing. The results showed that the manufactured products were in accordance with Technical Regulation of Identity and Quality - RTIQ for mortadella, established by Brazilian legislation. The sensorial analysis indicated that there was no significant difference $(p>0.05)$ among the formulated mortadella. These results show that poultry breasts with White Stripping and Wooden Breast can be used in emulsified products such as mortadella.

Key words: Emulsified meat products, physicochemical analysis, sensory analysis.

Resumo: Foram elaboradas formulações de mortadela utilizando peitos de frango com Decapagem Branca e Peito de Madeira para utilização desta matéria-prima. As mortadelas foram formuladas com 25\%, 50\%, 75\% e 100\% de mamas com WS ou WB e sem alterações (WA). Foram realizadas uma avaliação microbiológica, composição centesimal (proteína, umidade, lipídios e cinzas), pH e reação de Eber da mortadela formulada aos 30 e 60 dias pósprocessamento. Os resultados mostraram que os produtos manufaturados estavam de acordo com o Regulamento Técnico de Identidade e Qualidade - RTIQ para mortadela, estabelecido pela legislação brasileira. A análise sensorial indicou que não houve diferença significativa ( $>0,05$ ) entre a mortadela formulada. Estes resultados mostram que os peitos de aves com White Stripping e Wooden Breast podem ser usados em produtos emulsionados como a mortadela.
\end{abstract} sensorial.

Palavras chave: Produtos cárneos emulsionados, análise físico-química, análise

Autor para correspondência. E.Mail:

Recebido em 20.04.2019. Aceito 30.09.2019

http://dx.doi.org/ 10.5935/1981-2965.20190031

${ }^{1}$ Médicos Veterinários. Mestrado em Bioexperimentação. Universidade de Passo Fundo (UPF).

${ }^{2}$ Acadêmico de Medicina Veterinária. Universidade de Passo Fundo (UPF). Bolsista PIBIC CNPq.

${ }^{3}$ Médicos Veterinários. Doutores em Ciências Veterinárias. Docentes Universidade de Passo Fundo (UPF). 


\section{Introduction}

Characteristics of poultry cuts, such as appearance and softness, can be better perceived from the commercialization of boneless chickens, but this practice leaves apparent defects, which consumers reject (Beraquet, 1999). Industry disqualifies meats with White Striping (WS) and Wooden Breast (WB) and its use in formulated products would eliminate the aesthetic problem. However, Petracci et al. (2013) showed that meat with these changes has reduced technological properties, such as low water retention, low bonding ability and poor texture. Also Mudalal et al. (2014a) mention that the ability to bind the marinating solution and retain liquids during cooking is impaired in breasts with these changes.

Myopathy White Striping is characterized by whitish streaks on the surface of the muscle (Kuttappan et al., 2009) while the lesion WB is characterized by pale and hard areas, and may be accompanied by white streaks across the muscle pectoralis major (SIHVO et al., 2014).

In Brazil, it is the responsibility of the Ministry of Agriculture, Livestock and Food Supply (MAPA) to regulate and inspect the industries, assessing whether the requirements pertaining to hygienicsanitary legislation are met. Any carcass, or part of carcass, and organs with lesions or abnormalities that may be unfit for consumption must be forward directly to the Department of Final Inspection (DIF) which will be evaluated after complete examination (Brasil, 1952, 1998).

Currently, there is no official judgment criterion in Brazilian legislation on acceptability or total rejection of breasts with WS and WB alterations, probably due the recent appearance of these changes. In absence technical criteria, supervisors have adopted restrictive measures, considering these defects as "disgusting aspect" (Brasil, 1998) and directing these cuts to manufacture by-products, as meat and bone meal, later used in formulation of animal food.

According to Technical Regulation of Identity and Quality - RTQI (Brasil, 2000) mortadella is the industrialized meat product, obtained from a meat emulsion, with or without bacon, added with ingredients, embedded in natural or artificial casing, in different forms, and subjected to appropriate heat treatment. Mortadella made of chicken must have the following physicochemical characteristics: maximum limits of $10.0 \%$ total carbohydrates; $5.0 \%$ starch; $65.0 \%$ 
moisture and $30.0 \%$ fat, at least $12.0 \%$ protein and a calcium content of the dry matter of $0.6 \%$. From microbiological evaluations, the shelf life used by most industries is 90 days.

\section{Material and Methods}

Poultry breasts were obtained from a slaughterhouse under Federal Inspection in northern Rio Grande do Sul, after identification of WS and WB alterations. The training of inspection agents (Zanetti et al., 2018) followed the macroscopic classification recommended by Kuttappan et al. (2012): Normal: no visible white striations; moderate WS: striations visible on the muscle, but measuring less than one (1) $\mathrm{mm}$; severe WS: striation measuring more than one (1) $\mathrm{mm}$ and easily observed on the surface of the breast muscle; WB: pale areas expansive with white striation across the breast. However, for the assessment of condemnations, the breasts were grouped into normal (no change) or abnormal (with changes - WS and/or WB). Were collected $52 \mathrm{~kg}$ of meat for each alteration and $82 \mathrm{~kg}$ of breasts without alterations to elaborate nine formulations of mortadella, as follows: a) Sample 1: Mortadella with $25 \%$ WS or WB meats and $75 \%$ without alterations; b) Sample 2: Mortadella with $50 \%$ WS or WB meats and $50 \%$ without alterations; c) Sample 3: Mortadella with
$75 \%$ WS or WB meats and $25 \%$ without alterations; d) Sample 4: Mortadella with $100 \%$ WS or WB meats; Control Sample: Mortadella with $100 \%$ without alterations meats. For mortadella production, meats were weighed and ground on a $12 \mathrm{~mm}$ disk, homogenized with commercial condiments in a mechanical mixer, emulsified, embedded in pieces of $500 \mathrm{~g}$ and cooked in hot water tanks for 60 minutes in $60^{\circ} \mathrm{C}, 60$ minutes in $70^{\circ} \mathrm{C}$ and 60 minutes in $80^{\circ} \mathrm{C}$, until reaches $72^{\circ}$ to $75^{\circ} \mathrm{C}$ in the middle.

Microbiological, physicochemical analysis and sensorial analysis were carried out in Food Research Center (CEPA) laboratories at the Universidade de Passo Fundo - UPF. The microbiological tests recommended in Resolution 12 (BRASIL, 2001) were coliforms at $45^{\circ} \mathrm{C}$, coagulase positive Staphylococcus, Clostridium sulfite reductor at $46^{\circ} \mathrm{C}$ and Salmonella spp. absence in 25 grams of sample, carried out in accordance with IN 62 (BRASIL, 2003) and AOAC (2012). The centesimal composition test, $\mathrm{pH}$ and Éber test were carried out in accordance with the Normative Instruction $n^{\circ} 20$ from MAPA (Brasil, 1999).

Sensorial analysis of elaborated products was carried out with preference ordering and acceptability tests. The preference ranking test allows comparing 
three or more samples in relation to one attribute and was performed by 50 untrained judges with formulations made after 30 and 60 days of manufacture. The samples were coded, randomized and submitted to ranking test, which the judges were asked to order the samples according to their preference. Preference results were transformed into orders and sums of orders were calculated for each sample, which are statistically evaluated by the Friedman test.

The objective of the acceptability test is to assess the degree that consumers like or dislike a product. Fifty untrained judges were used. The samples evaluated were a control sample and two samples (one for each alteration) selected in the preference ranking test. The judges were asked to evaluate the samples according texture, flavor, color, consistence, odor and overall assessment, in grades 1 to 9, representing a scale whose extremes meant greatly disliked (1) and really liked (9). Results were evaluated by Analysis of Variance (ANOVA) and Tukey test for average comparison.

\section{Results and Discussion}

All mortadella formulations analyzed were in compliance with the microbiological standards found in RDC 12 (Brasil, 2001), considered for human consumption. The centesimal composition results of formulations of mortadella made from chicken breasts with and without WS and WB in compliance with brazilian legislation (Brasil, 1999).

The results showed that the protein content differed significantly in formulations with WS breasts, but attended the Technical Regulation of Identity and Quality - RTIQ for mortadella (Brasil, 1999). The highest protein levels observed in WS and WB breasts are desirable, because this attribute is considered one of the most important nutritional and technological terms, directly related to capacity of water retention and characteristics such as appearance and texture. In addition, proteins have properties such as gelling and emulsification capacity, essential for mortadella production (CUNHA, 2011).

For the lipid content, WS formulations differed significantly from the control samples, but also complied the respective regulation (Brasil, 1999). Kuttappan et al. (2012) describe that there is no difference in centesimal composition between moderate WS breasts and without alteration breasts, but breasts with severe WS presented higher lipid content and lower protein content in relation to breasts without alteration. Petracci et al. (2014) found that WS breasts differed from without alteration breasts $(p<0.05)$ due to increase in lipid content and decrease in 
Tedesco \& Schneider

(2016)

protein content.

On the other hand, moisture contents are in disagreement with the current legislation, probably due to the manufacturing process, since at the mass emulsifying moment there was an overheating because only skinless breasts were used as the raw material and no fat has been added or Mechanically Separated Meat (CMS). Thus, a larger quantity of cold water was added in order to facilitate the preparation and embedding the mass, which should be corrected in future formulations.

Pork fat was not added in the mortadella to avoid interfering the sensorial analysis of the formulations tested. Thus, fat values verified in centesimal composition were lower than those established in the legislation, while protein levels were higher, denoting a product of higher nutritional quality regarding the provision of proteins.

There was no statistically significant difference ( $p>0.05$ ) between the mortadella made with respect to $\mathrm{pH}$, with mean values of 6.39 for formulations with WS breasts, 6,41 for formulations with WS breasts and 6.37 for mortadella prepared with chicken breast without alterations, as well as negative results for Éber test. evaluated the quality attributes of chicken breasts with WS or WB determining centesimal composition, $\mathrm{pH}$, color, shear force, water retention capacity and weight loss by cooking. Breasts affected with White Striping presented significant difference $(\mathrm{p}<0,05)$ for $\mathrm{pH}$, shear force and water retention capacity. In breasts identified with Wooden Breast, there was a significant difference $(\mathrm{p}<0,05)$ in protein, moisture, ash, $\mathrm{pH}$, shear force and water retention capacity. The authors concluded that chicken breasts with these myopathies can be used in processed products, reducing food waste and losses to poultry industry.

Regarding sensory analysis, which comprised texture, taste, color, consistency and odor attributes, there was no significant difference in products formulated after 30 and 60 days. The methods of ordering preference and acceptability showed similar results among the formulations with $25 \%, 50 \%, 75 \%$ and $100 \%$ of breasts with WS or WB alterations when compared to formulations of chicken breasts without alterations after 30 and 60 days of manufacture.

Meat products are preferably obtained from fresh meat which undergoes one or more type of process, such as 
cooking, salting, curing or just adding condiments and seasonings. The processing of fresh meat aims, besides to elaborate new products, the perishability reduction, problems in shipping and storage and advantages in relation to increased shelf life. The processing does not significantly modify original nutritional qualities, however, attributes characteristics such as color, flavor and aroma characteristic of each process. The main highlight of meat processing is the value aggregation to the product, with cuts that would not be used for consumption in natura, creating alternatives for its commercialization. Thus, there is a development stimulus of industrialization of derived products, contributing to job creation and increasing the income and supply of commercially available products (BRASIL, 2016).

In this context, the use of chicken breasts with WS and WB alterations, currently discarded in industries, would be an economically viable alternative, safe and sensorial acceptable for this purpose.

\section{Conclusion}

Poultry meat with White Striping and Wooden Breast can be used in manufacture of emulsified mortadella, regardless of the proportion in its formulation. The meat refining process, allied to cooking, suppresses the undesirable characteristics that in natura cuts present, such as stiffness and poor appearance, which lead industry and consumers to reject these meats.

\section{References}

1. AOAC. Official Methods of Analysis. Microbiological Methods, 2012.

2. BERAQUET, N. Influência de fatores ante e post mortem na qualidade da carne de aves. Rev. Bras. de Ciência Avícola, n.1, p.155$166,1999$.

3. BRASIL. Decreto-lei $n^{\circ} .30 .691$, de 29 de março 1952. Estabelece Regulamento da Inspeção Industrial e Sanitária de Produtos de Origem-Animal (RIISPOA).

4.BRASIL. Portaria $n^{\circ} 210$, de novembro de 1998. Regulamento técnico da inspeção tecnológica e higiênico sanitária de carnes de aves. Ministério da Agricultura Pecuária e Abastecimento, Brasília, 1998. Publicado no Diário Oficial da União de 26/11/1998, Seção 1, p.226.

5. BRASIL. Instrução Normativa $\mathrm{n}^{\circ} 20$. Métodos físico-químicos para controle de produtos cárneos e seus ingredientes - sal e salmoura. Ministério da Agricultura, Pecuária e Abastecimento, Brasília, 21 de julho de 1999.

6. BRASIL. Instrução Normativa $n^{\circ} 4$, de 31 de março de 2000. Regulamento Técnico de Identidade e Qualidade de mortadela. Ministério da Agricultura, Pecuária e Abastecimento, Brasília, 2000.

7. BRASIL. Resolução da Diretoria Colegiada $\mathrm{n}^{\circ} 12$, de 02 de janeiro de 2001. Regulamento Técnico sobre Padrões Microbiológicos para Alimentos. Agência Nacional de Vigilância Sanitária, Brasília, 2001.

8. BRASIL. Instrução Normativa $n^{\circ} 62$, de 26 de agosto de 2003. Regulamento Técnico para Análises Microbiológicas para Controle de Produtos de Origem Animal e Água. Ministério da Agricultura, Pecuária e Abastecimento, Brasília, 2003. 
9. BRASIL. Empresa Brasileira de Pesquisa Agropecuária (EMBRAPA). Disponível em: <http://www.agencia.cnptia.embrapa.br/>.

Acesso em: 07 jul. 2016.

10. CUNHA, A. D. Elaboração do padrão de identidade e qualidade de embutido defumado a base de carne de frango "Quitute". 2011. 60 f. Trabalho de Conclusão de Curso (Curso Superior de Tecnologia de Alimentos)- Instituto Federal de Educação, Ciência e Tecnologia do Rio Grande do Sul, Bento Gonçalves, 2011.

11. KUTTAPPAN, V.A.; BREWER, V.B.; CLARK, F.D.; MCKEE, S. R.; MEULLENET, J.F.C.; EMMERT, J. L.; OWENS, M. C. Effect of white striping on the histological and meat quality characteristics of broiler fillets. Poultry Science, v. 88, n. 447, (Abstr.), 2009.

12. KUTTAPPAN, V.A.; LEE, Y.S.; ERF, G. F.; MEULLENET, J.F.C.; McKEE, S.R.; OWENS, C.M. Consumer acceptance of visual appearance of broiler breast meat with varying degrees of white striping. Poultry Science, v. 91, n. 5, p. 1240-1247, jan. 2012.

13. MUDADAL, S.; BABINI, E.; CAVANI, C.; PETRACCI, M. Quantity and functionality of protein fractions in chicken breast fillets affected by white striping. Poultry Science, v. 93, p. 2108-2116, maio 2014a.

14. PETRACCI, M.; MUDALAL, S.; BONFIBLIO, A.; CAVANI, C. Occurrence of white striping under commercial conditions and its impact on breast meat quality in broiler chickens. Poultry Science, v. 92, n. 6, p. 16701675, fev. 2013.

15. PETRACCI, M.; MUDALAL, S.; BABINI, E.; CAVANI, C. Effect of White striping on chemical composition and nutritional value of chicken breast meat. Italian Journal of Animal Science, v. 13, p. 179-183, jan. 2014.

16. SIHVO, H.K.; IMMONEN, K.; PUOLANNE, E. Myodegeneration with fibrosis and regeneration in the Pectoralis major muscle of broilers. Veterinary Pathology, v. 51, n.3, p. 619-623, 2014.
17. TEIXEIRA, S.T.F. Estudo anátomopatológico do músculo Pectoralis major de frangos de corte acometidos com White Striping e Wooden Breast. 2015. $69 \mathrm{f}$. Dissertação (Mestrado em Bioexperimentação)- Universidade de Passo Fundo, Passo Fundo, 2015.

18. TEDESCO, D.C.; SCHNEIDER, T. Atributos de qualidade de carne em peitos de frango com alterações White Striping ou Wooden Breast. 2016. 32 f. Trabalho de Conclusão de Curso (Curso de Engenharia de Alimentos)- Universidade de Passo Fundo, Passo Fundo, 2016.

19. ZANETTI, M.A.; TEDESCO, D.C.; SCHNEIDER, T.; TEIXEIRA, S.T.F.; DAROIT, L.; PILOTTO, F.; DICKEL, E.L.; SANTOS, S.P.; SANTOS, L.R. Economic losses associated with Wooden Breast and White Striping in broilers. Semina: Ciências Agrárias, v.39, n.2, p. 887-892, 2018. 